\title{
Macro Structures, Superstructures, and Micro Structures in Polygamous Themed Novels by Habiburrahman El Shirazy
}

\author{
Lina Putriyanti ${ }^{1}$, Rustono ${ }^{2}$, Fathur Rokhman ${ }^{3}$, Subyantoro ${ }^{4}$ \\ \{linaputriyanti@gmail.com¹, rus_tono58@yahoo.co.id ${ }^{2}$, rektor@mail.unnes.ac.id ${ }^{3}$, \\ bintoro@mail.unnes.ac.id $\left.{ }^{4}\right\}$
}

Graduate School Universitas Negeri Semarang, Indonesia ${ }^{1,2,3,4}$

\begin{abstract}
The critical discourse analysis (CDA) of Teun A van Djik consists of macro structures, superstructures, and micro structures. In discussing the Ayat-Ayat Cinta novel by Habiburrahman El Shirazy which contains the theme of polygamy CDA theory is needed. The research approach is CDA van Djik. The technique is to uncover the structure of the text and the recorded technique as an advanced technique. The data is in the form of fragments of text while the data source is the Ayat-Ayat Cinta novel. Techniques for data triangulation to test the validity of data and data analysis required interactive techniques and CDA van Djik. Research results include; macro structure: polygamous marriage, superstructure: request from first wife so that her husband remarries, and micro structure; (a) semantic structure: found feelings of jealousy from the first wife, (b) stylistics: pronoun "brother" and "sister" to show the inter-wife friendliness. The research objective was to find macro structures, superstructures, and microstructure. The benefits of research for the development of discourse science and as a reference in understanding the structure of the text. Conclusions found polygamous marriage and sincerity needed.
\end{abstract}

Keywords: text structure, critical discourse analysis, novel, polygamy

\section{Introduction}

The issue of polygamy marriage in the community, especially the Indonesian people is always interesting to be discussed and never goes out. Always found positive and negative sides in responding to polygamous marriages both from religion, especially Islam or social reality. The phenomenon of polygamous marriage is a concern for writers in Indonesia. One of them is Habiburrahman El Shirazy in his work entitled Ayat-Ayat Cinta [1] trying to package polygamous marriages through the eyes of men. Polygamy marriage is considered as the last solution or choice of problems faced and the importance of permission from the first wife. While in other studies that were dissected from the theory of framing analysis showed that the issue of polygamy by the director of the film "Surga Yang Tak Dirindukan", was represented as 'paradise' which was never desired by women. From the title it has been "obvious" that there is a meaning of women's rejection of polygamy. The director in the film does not explicitly state whether it agrees or rejects the concept of polygamy [2]. 
Research in exploring the structure of the text was also found in research carried out by Martono and Mulyani [3]. However, there are some differences with this study. Martono and Mulyani's research found a macro structure with the theme "Fireball Corruption KTP". The superstructure is found in the introduction, the contents and the absence of conclusions. In the micro structure discourse is found that uses effective, direct sentences and diction. Previous studies raised the theme and dissected with different theories from this study. Researchers in this study raised the theme of polygamy marriage that occurred in literature and dismantled the structure of the text through CDA theory.

Furthermore, Martono and Mulyani [3] suggested that the CDA influenced the branches and sub-branches of humanities and applied linguistics a little more. In this CDA theory, language is seen as a strong container to represent a strong ideology, identity and culture of society. Through the power of language, their intentions, ideologies, and thoughts can be known. This is an effective way to polarize power in society. CDA is intended to identify and study specific fields such as injustice, inequality, racism, danger, suffering, prejudice, and the like.

Practitioners (Kres, Hodges \& Kress, Fairclough, van Djik, and Wodak) summarize the principles of CDA into seven components namely; (a) language is social practice, (b) discourse is used as social practices such as power, domination, resistance etc., (c) there is a dialectical relationship between text and social subjects, (d) non-arbitrary structures and features, (e) discourse can connecting between power, production, implementation and reproduction, (f) discourse is historical, (g) CDA has the duty to interpret the text including also explain, and $(\mathrm{h})$ in the practice of discretion, the writer and the speaker have special interests and goals [4].

Teun A van Djik (in Eriyanto) suggests that the structure of the text is divided into three, namely macro structure, superstructure, and micro structure. (a) Macro structure (thematic) is a meaning that includes a whole that is in the text, (b) superstructure (schematic / plot) is the path of storytelling that begins with the precursor, contents, concluding then ends with conclusions, and (c) structure micro consists of semantic aspects which are local meanings of a text observed from (background, detail, intent, and presuppositions), stylistic (lexicon), and rhetorical (graphic, and metaphoric) [5].

Based on the background described above, problems can be formulated, namely how to analyze the macro structure, superstructure, and micro-structure with the theme of polygamy in the Ayat-Ayat Cinta novel by Habiburrahman El Shirazy. The research objective was to find macro structures, superstructures, and micro structures that contained the theme of polygamy in the novel Ayat-Ayat Cinta by Habiburrahman El Shirazy. And this research has benefits for the development of discourse and as a reference in understanding the structure of the text. Important research is needed because so far the theme of polygamy has been dissected through the theories of Al Quran, psychology, and law. And researchers dissect text structures in linguistics.

\section{Methods}

This study included a type of qualitative descriptive research [6]. The theory of critical discourse analysis (CDA) Teun A van Djik is a scalpel for research and critical language analysis as an approach. The research data is in the form of text fragments from research data sources, namely the Ayat-Ayat Cinta novel by Habiburrahman El Shirazy. The research 
technique used is the referral technique and note taking technique as follow. Data cards as research instruments. Data triangulation is used to check the correctness of data [7]. To analyze data using interactive analysis techniques [8] and Critical Discourse Analysis (CDA) Teun A. Van Dijk. Based on the method it can be concluded that this method is most effectively used in this study to find the text structure (macro structure, superstructure, and micro structure).

\section{Result and Discussion}

In the results and discussion there are three topics discussed in this study, namely macro structure (thematic), superstructure (schematic), and micro structure.

\subsection{Macro Structure}

Macro structure in critical discourse analysis is the overall meaning that can be observed from the theme or topic of a discourse. This time, the theme reviewed by researchers is polygamous marriage. The theme of polygamous marriage is always a "scourge" for the people. This is shown through the following quote.

"If you really love me then you must try to do the best for our child. I'm a mom soon. And a mother will do anything for the father of her child. Marry Mary. And you will save many people. You saved Maria. Save our child. Save myself from the status of a widow who continues to imagine before my eyes and save your own good name. "(AAC 2008: 377)

The sentence above is the initial presentation of Habiburrahman El Shirazy as the author of his perspective on polygamy. The statement emphasizes the role and power of a woman (first wife) in determining polygamy. This can confirm that polygamy is considered to be the best solution to the problem that is shackling. Polygamy is represented by Habiburrahman El Shirazy as a positive form.

\subsection{Superstructure}

In the superstructure, things that need to be observed are introduction, content and closing. In the Ayat-Ayat Cinta novel a superstructure is found. Habiburrahman El Shirazy as the author opened it with a series of sentences that were " neat ".

"I will ask Aisha to give her mercy to Maria. I'm sure Aisha is a good-hearted, pious woman. It happened to be him, just arrived. You wait here with Boutros. I want to talk privately with Aisha. The two then walked into a room. I don't know what Madame Nahed would say to Aisha. Hopefully Aisha is not hurt. And I have no intention at all for a second to make Aisha and Maria. I never thought that Mary loved me in such a way. "(AAC 2008: 376)

The above statement is a precursor to polygamous marriage. The sentence above implies that Aisha was considered the first wife who was willing to be polygamous and Fahri's figure actually did not want polygamy and hurt his first wife. And polygamy must be done for the humanitarian side of maria who is seriously ill. Statement after statement affirms that polygamy flows and must be taken without any other choice. 
"Marry him, for the sake of our child. Please! If Mary does not give her testimony, then I do not know what else to do to save the father of this child I bear. "A drop of clear water comes out of the corner of his eye." (AAC 2008: 376)

"After that I went to see Madame Nahed and Mr. Boutros. They both welcomed my willingness happily. The marriage contract process is carried out in a very fast, simple time, according to my request. A ma'dzun syar'i representing Mr. Boutros married me to Maria with the dowry of a gold ring. The witness was two Muslim doctors who were in the hospital. "(AAC 2008: 378)

Superstructure analysis in CDA also criticizes the content section. The series of sentences above are contents. Aisha's imposition of Fahri in order to marry Mary looked very firm and clear. Although there is an insincerity from the first wife, but it must be lived. And finally, Fahri married Maria for the approval of Aisha as the first wife and family blessing.

"Ia tetap tersenyum. Menatapku tiada berkedip. Perlahan pandangan matanya meredup. Tak lama kemudian kedua matanya yang bening itu tertutup rapat. Kuperiksa napasnya telah tiada. Nadinya tiada lagi denyutnya. Dan jantungnya tiada lagi terdengar detaknya. Aku tak kuasa menahan derasnya lelehan air mata. Aisha juga. Inna lillahi wa inna ilaihi raajiun!." (AAC 2008:402)

The sentence above shows the closing superstructure. The polygamous marriage between Fahri, Aisha and Maria was very short and ended tragically. Maria's death as Fahri's second wife ended the polygamous marriage story she lived with Aisha.

\subsection{Micro Structure}

The microstructure analysis of a discourse focuses on a meaning the author wants to convey to the reader in the Ayat-Ayat Cinta novel.

Semantik. In CDA, semantics can be categorized as local meanings. Multiple meanings can be had in local meanings. This role of language is often used as a medium to lead issues, interests, and submit opinions. The following are described data as well as discussions related to the semantic domain.

"I was silent, I could not say anything. I never imagined that I would face a psychological atmosphere that was quite heavy like this. Aisha took the dowry ring that I gave on the ring finger of her right hand. "(AAC 2008: 378)

"This is a dowry for Mary. The time is very urgent. Before maghrib you must have arrived in prison. So you have to get married soon and do all the doctor's instructions to make Maria aware. "Aisha's words were so firm without any doubt, as firm as Palestinian women when they told her husband to go to the field of jihad. With a little hesitation I took the ring. I can't hold back my sobs. Aisha hugs me, we cry. "(AAC 2008: 378)

The statements above are a form of assertiveness of the first wife (Aisha) and Fahri's compulsion and helplessness to marry Mary. Aisha's insistence on Fahri wanting to marry Mary was very strong. Marrying Fahri and Maria will make things better.

Stylistics. Stylistics is the choice of words used by the author to convey his message, purpose and ideology. The following data contains stylistics. 
"Now it's not only Madame Nahed and her family who feel responsible for waiting for Maria. Aisha felt she had a strong soul. He was very faithful in waiting for me and waiting for Maria. He even often sleeps while sitting next to Maria. Aisha considered Maria like her own sister. Several times I forced myself to get out of bed and accompany Aisha waiting for Aisha. "(AAC 2008: 389 390)

"He pushed me to marry you. This ring in your hand is Aisha's gift. Think of him as your brother. "(AAC 2008: 380)

The choice of pronoun stylist "sister" for the designation of the second wife and "brother" for the term first wife in the fragment of the text above shows the intimacy between the wives. The author seems not to give the distance between the first and second wives. So, the pronouncement "sister" and "brother" can imply a family side between them.

Rhetorical. Rhetorically in the theory of critical discourse analysis related to graphics and metaphor. In this study the things that want to be examined from rhetoric are graphics. Here's a graphic presentation.

"We then talked about each other's hopes. The ideals and idealism of each. I feel that what is expected and aspired by Aisha is no different from what I expected and I aspired to. He wants a husband who wholeheartedly loves him, makes himself his only wife, faithful in joy and sorrow, attention to the family, and does not neglect the task of fighting in the way of God. That is also what I want from my wife. I want a wife who is virtuous, faithful and does not betray God and His Messenger." (AAC 2008: 217)

The above quote shows graphics. The graphics in critical discourse analysis is something that must be interpreted in a discourse. The series of sentences shows that there was an agreement between Aisha and Fahri at the beginning of the marriage to never be ambiguous or polygamous. However, polygamy was forced to do because of situations and conditions that were never suspected.

Payuyasa [9] conducted a similar study using Teun A van Djik's CDA theory. Payuyasa raised the theme of the Mata Najwa program "Babak Final Pilkada Jakarta" and produced three text structures. Macro structure, superstructure, and micro structure. With this research can enrich previous research that is useful for the development of discourse science and as a reference in understanding the structure of the text.

\section{Conclusion}

The three text structures analyzed through the CDA theory of Teun A van Djik in this study produced three structures. First, the macro structure or theme in this study is about polygamous marriage. Second, the superstructure or groove containing the introduction, contents, and closing. Third, micro structures related to semantic, stylistic, and rhetorical elements indicate that some of these discourses contain explicit and implicit meanings. The explicit meaning conveyed by the author that he was forced to polygamy and polygamy marriage as a way out of the problem. While from the charge of implicit meaning, there is a real insincerity from the first wife. 


\section{References}

[1] Shirazy, Habiburrahman El. Ayat-Ayat Cinta 1. Jakarta:Penerbit Republika. (2008)

[2] U. Masyarrofah et al., "Analisis Framing Tentang Poligami Dalam Film Surga Yang Tak Dirindukan,” vol. 13, no. 1, pp. 61-75, 2017.

[3] C. M. Bonina, "The London School of Economics and Political Science G OVERNMENT : A C RITICAL D ISCOURSE A NALYSIS OF Carla M . Bonina London School of Economics and Political Science," vol. 3, no. 1, pp. 1-8, 2007.

[4] N. H. S. Bukhari and W. Xiaoyang, "Critical Discourse Analysis and Educational Research," vol. 3, no. 1, pp. 9-17, 2013.

[5] [5] Eriyanto. Analisis Wacana: Pengantar Analisis Teks Media. Yogyakarta: PT. LKiS Printing . (2012)

[6] Sugiyono. Metode Penelitian Pendidikan (Metode Penelitian Kuantitatif, Kualitatif dan R\&D). Bandung: Alfabeta. [2008]

[7] Sudaryanto. Metode dan Aneka Teknik Analisis Bahasa. Yogyakarta: Gadjah Mada University Press. (1993)

[8] Miles, M.B, Huberman, A.M. dan Saldana, J. Qualitattive Data Analysisi, A Methods Sourcebook Edition 3. USA: Sage Publications. (2014)

[9] I. N. Payuyasa, "Analisis Wacana Kritis Model Van Dijk Dalam Program Acara Mata Najwa di Metro TV," vol. 5, no. November, pp. 14-24, 2017. 